\title{
STUDI KOMPARATIF THE DAY OF THE WEEK EFFECT DAN THE MONTH OF THE YEAR EFFECT DALAM PEROLEHAN RETURN SAHAM DI BURSA EFEK INDONESIA PADA PERUSAHAAN LQ 45 PERIODE FEBRUARI 2017-JANUARI 2018
}

\author{
Komang Agus Rudi Indra Laksmana ${ }^{1}$ \\ Ni Luh Gede Sri Artika Dewi \\ ${ }^{1}$ Program Studi Manajemen, Fakultas Ekonomi, Universitas Mahendradatta \\ Jl. Ken Arok No 12, Peguyangan Denpasar Utara, Bali 80115 \\ ${ }^{1}$ Email : ilaksmana70@gmail.com \\ ${ }^{2}$ Email : Sri.artikadewi96@gimail.com
}

\begin{abstract}
ABSTRAK
Abstrak - Konsep pasar modal yang efisien telah menjadi suatu topik perdebatan yang menarik dan cukup kontroversial di bidang keuangan. Semenjak dikemukakannya hipotesis pasar efisien, muncul berbagai perilaku ketidakteraturan atau penyimpangan dalam pasar modal. Ketidakteraturan ini disebut sebagai anomali pasar (market anomaly). Anomali pasar yang menjadi banyak perhatian adalah anomali efek kalender. Anomali ini diantaranya adalah the day of the week effect dan the month of the year effect. Penelitian ini dilakukan karena adanya hasil beberapa penelitian yang tidak konsisten mengenai the day of the week effect dan the month of the year effect dalam perolehan return saham di Bursa Efek Indonesia. Hasil penelitian menemukan bahwa terjadi fenomena the month of the year effect di Bursa Efek Indonesia dan tidak ditemukan fenomena the day of the week effect
\end{abstract}

Kata kunci : The Day Of The Week Effect, The Month Of The Year Effect, Abnormal Return

Abstract - The concept of the efficient capital markets has become a topic of debate is fascinating and quite controversial in the field of finance. Since the introduction his the efficient market hypothesis, comes a variety of behavior of irregularity or discrepancy in the capital markets. Irregularity is referred to as a market anomaly (market anomaly). The Market anomaly that became a lot of attention is the anomalous effect of calendar. These anomalies are the day of the week effect and the month of the year effect. This research was conducted due to the results of several studies that are not consistent on the day of the week effect and the month of the year effect in obtaining the return of shares in Indonesia stock exchange.

Keywords: The Day Of The Week Effect, The Month Of The Year Effect, Abnormal Return 


\section{PENDAHULUAN}

Konsep pasar modal yang efisien telah menjadi suatu topik perdebatan dan yang menarik dan cukup kontroversial di bidang keuangan, baik bagi kalangan akademisi maupun praktisi. Istilah tentang pasar efisien memang bisa diartikan secara berbeda untuk tujuan yang berbeda pula. Untuk bidang keuangan, konsep pasar yang efisien lebih ditekankan pada aspek informasi, artinya pasar yang efisien adalah pasar dimana harga semua sekuritas yang diperdagangkan telah mencerminkan semua informasi yang tersedia. Menurut Fama(1970) Gumanti dan Utami(2002), ada tiga bentuk tingkat efisiensi pasar berdasarkan pada tingkat

penyerapan informasinya, yaitu pasar efisien bentuk lemah, pasar efisien bentuk semi kuat, pasar efisien bentuk kuat.

Penelitian ini dilakukan karena adanya hasil beberapa penelitian yang tidak konsisten mengenai the day of the week effect dan the month of the year effect dalam perolehan return saham di Bursa Efek Indonesia. Disamping itu, penelitian tentang anomali pasar efisien pada suatu negara menjadi sangat penting karena hasilnya mempunyai implikasi yang sangat signifikan bagi investor dan manajer investasi dalam menentukan strategi investasi

Bursa Efek Indonesia pada tahun 2017 memiliki 570 emiten, berikut tabel kinerja index Bursa Efek Indonesia tahun 2017 :

Tabel 1.1

Kinerja Indeks Saham Bursa Efek Indonesia

\begin{tabular}{|l|r|r|r|r|}
\hline $\begin{array}{l}\text { Indeks } \\
\text { Saham }\end{array}$ & \multicolumn{1}{|l|}{$\begin{array}{l}\text { Annualized } \\
\text { Risk }\end{array}$} & \multicolumn{1}{l|}{ Korelasi } & \multicolumn{1}{c|}{ Beta } \\
\hline SRI-KEHATI & $22.60 \%$ & $11.54 \%$ & $91.35 \%$ & 1.25 \\
\hline BISNIS27 & $20.99 \%$ & $11.95 \%$ & $93.50 \%$ & 1.32 \\
\hline IDX30 & $20.20 \%$ & $11.52 \%$ & $95.64 \%$ & 1.30 \\
\hline LQ45 & $18.10 \%$ & $11.15 \%$ & $97.13 \%$ & 1.28 \\
\hline IHSG & $16.74 \%$ & $8.46 \%$ & $100.00 \%$ & 1.00 \\
\hline KOMPAS100 & $16.60 \%$ & $10.46 \%$ & $98.64 \%$ & 1.22 \\
\hline JII & $6.34 \%$ & $11.59 \%$ & $88.08 \%$ & 1.21 \\
\hline PEFINDO25 & $-10.24 \%$ & $15.33 \%$ & $40.39 \%$ & 0.73 \\
\hline
\end{tabular}

\section{Sumber: www.infovesta.com}

Dari tabel diatas dapat dilihat kinerja selama year-to-date ditahun 2017. Dari sisi return indeks SRI-KEHATI memiliki return yang paling tinggi, dimana berinvestasi pada 25 saham pada SRI KEHATI, 30 saham di IDX30, 45 saham di LQ45 dan 100 saham di
KOMPAS100. SRI KEHATI sendiri konsisten membukukan kinerja diatas IHSG berturut-turut selama 5 tahun terakhir. Sementara saham PEFINDO25 kurang menarik di tahun 2017 terlihat dari kinerja indeksnya yang justru negatif. Dari sisi diversifikasi 
memiliki 100 saham dengan kapitalisasi terbesar pergerakanya berkorelasi positif hingga $99 \%$ dengan memiliki seluruh saham di bursa artinya pergerakan KOMPAS100 hampir selalu searah dengan pergerakan IHSG.

\section{TINJAUAN TEORITIS}

\section{Konsep Pasar Modal Yang Efisien}

Dalam konsep pasar modal yang efisien menurut Jogiyanto(2005:1), disebutkan ada tiga macam pasar efisien, yaitu pasar efisien secara informasi yang dikembangkan oleh Fama(1970), pasar efisien secara operasional dan pasar efisien secara keputusan yang dikembangkan oleh Jogiyanto (2003).Pasar efisien secara informasi didasarkan pada ketersediaan informasi dimana pasar dikatakan efisien jika pasar bereaksi dengan cepat dan akurat untuk mencapai harga keseimbangan baru yang sepenuhnya mencerminkan informasi yang tersedia. Efisiensi pasar secara informasi disebut juga efisiensi secara eksternal

Pasar efisien secara operasional lebih ditekankan pada operasi pasar. Pasar dikatakan efisien secara operasional jika operasi pasar dapat dilakukan dengan cepat dan biaya murah. Efisiensi pasar secara operasional menunjukkan kemampuan pasar modal yang menyediakan likuiditas, eksekusi transaksi dengan cepat dan biaya perdagangan yang rendah. Kondisi pasar seperti ini disebut pasar yang likuid., sehingga efisiensi pasar yang operasional disebut juga efisiensi secara internal. Jogiyanto(2005) menjelaskan bahwa informasi saja tidak cukup untuk membuat pasar efisien. Efisiensi pasar juga perlu dilihat berdasarkan kecanggihan pasar dalam mengelola informasi untuk pengambilan keputusan dengan benar. Konsep pasar efisien adalah pasar dimana pelakunya bertransaksi secara adil (fair game). Adil disini berarti tidak ada pihak yang dirugikan secara tidak normal. Pasar efisien seperti ini hanya dapatr terjadi jika informasi sudah menyebar secara penuh, cepat, serta pasarnya pintar mengambil keputusan dengan benar. Jogiyanto memberinya nama pasar efisien secara keputusan.

\section{Pengujian Efisiensi Pasar}

Pengujian pasar efisien dituangkan dalam suatu hipotesis pasar efisien. Pengujian secara empiris perlu dilakukan untuk masing-masing bentuk efisiensi pasar untuk mengetahui kebenaran dari hipotesis ini. Jogiyanto(2005:397) menyebutkan bahwa Fama(1970) membagi pengujian efisiensi pasar dalam tiga kategori yang dihubungkan dengn bentuk-benruk efisiensi pasarnya sebagai berikut :

1) pengujian-pengujian bentuk lemah (weak form test), yaitu seberapa kuat informasi masa lalu dapat memprediksi return masa depan.

2) Pengujian-pengujian bentuk setengah kuat (semi strong form test), yaitu seberapa cepat harga 
sekuritas merefleksikan informasi yang dipublikasikan

3) Pengujian-pengujian bentuk kuat (strong form test), yaitu untuk menjawab pertanyaan apakah investor mempunyai informasi privat yang tidak terefleksi pada harga sekuritas.

Dalam artikel selanjutnya, Fama(1991) dalam Jogiyanto(2005:397) mengusulkan untuk mengubah nama ketiga macam kategori pengujian bentuk efisiensi pasar tersebur sebagai berikut :

1) Pengujian-pengujian efisiensi bentuk lemah diganti menjadi pegujian-pengujain terhadap pendugaan return. Pengujian efisiensi pasar bentuk lemah melibatkan pertanyaan apakah informasi yang terkandung pada harga-harga sekuritas masa lalu yang berurutan telah secara penuh mencerminkan harga sekarang. Hipotesis untuk menguji bentuk lemah ini berhubungan dengan hipotesis langkah acak. Jika harga-harga mengikuti pola langkah acak, maka perubahan harga dari waktu ke waktu sifatnya adalah random independen.

2) Pengujian-pengujian efisiensi bentuk setengah kuat diganti menjadi studi peristiwa. Penelitian tentang bentuk efisiensi setengah kuat ditujukan untuk mengetahui apakah hargaharga benar-benar mencerminkan informasi yang dipublikasikan. Hipotesis yang digunakan adalah bahwa segera setelah informasi menjadi milik publik, investor tidak bisa memperoleh abnormal return. Abnormal return adalah selisish antara return sebenarnya dengan return yang diharapkan. Return yang diharapkan dihasilkan menggunakan model tertentu. Model yang paling sering digunakan adalah market model dan capital asset pricing model.

3) Pengujian-pengujian efisiensi pasar bentuk kuat diusulkan menjadi pengujian terhadap informasi privat. Pengujian ini dilakukan terhadap hipotesis yang menyatakan bahwa harga saham tidak hanya mencerminkan semua informasi yang dipublikasikan, tetapi juga informasi yang mungkin tidak diketahui umum. Pengujian terhadap hipotesisi ini dilakukan dengan cara menganalisis prestasi dari berbagai portofolio yang dikelola oleh kelompokkelompok yang mungkin mempunyai informasi khusus. Bila terdapat portofolio yang bisa memberikan return yang lebih besar dari return pasar secara keseluruhan dan berlangsung terus menerus, maka dikatakan bahwa pasar modal tidak dalam keadaan efisien.

\section{Pengujian-pengujian Pendugaan Return}

Pengujian-pengujian pendugaan return akan dibahas lebih detil dalam skripsi ini karena penelitian ini melibatkan pengujian efisiensi pasar bentuk lemah. Pengujian efisiensi pasar bentuk lemah melibatkan pertanyaan apakah informasi yang terkandung pada harga-harga sekuritas masa lalu yang berurutan telah secara penuh 
tercermin pada harga sekarang. Pengujian bentuk lemah berhubungan dengan hipotesis langkah acak.Jika harga-harga mengikuti pola langkah acak, perubahan harga dari waktu ke waktu sifatnya adalah random yang independen. Ini berarti bahwa perubahan harga hari ini tidak ada hubungannya dengan perubahan harga kemarin atau hari-hari sebelumnya.

Pengujian efisiensi pasar bentuk lemah dapat dilakukan dengan cara pengujian statistik atau dengan cara pengujian menggunakan aturan-aturan teknis. Pengujian secara statistik dapat dilakukan dengan menguji independensi dari perubahanperubahan harga sekuritas. Jika hasil pengujian menunjukkan independensi harga-harga, implikasinya adalah investor tidak dapat menggunakan nilai-nilai masa lalu dari variabel-variabel penduga seperti harga, return, dividen, yield, atau tingkat suku bunga untuk menduga harga atau return sekarang. Pasar yang efisien secara bentuk lemah dicirikan dengan adanya perubahan-perubahan harga sekuritas yang independen terhadap nilai masa lalu variabel-variabel penduga. Pengujian statistik yang dilakukan untuk menguji independensi adalah pengujian hubungan variabel menggunakan korelasi serial atau regresi linear dan run test.

Pengujian pasar efisien bentuk lemah dilakukan untuk menguji ada tidaknya hubungan antara harga atau return sekuritas masa lalu dengan harga atau return sekuritas masa sekarang atau masa mendatang. Hubungan linier antara dua periode perubahan harga dapat diestimasikan dengan menggunakan koefisien korelasi atau dengan menggunakan teknik regresi. Jika perubahan harga antarperiode tidak signifikan, dimana hal ini menunjukkan adanya independsi harga sekuritas dari satu periode ke periode lainnya, berarti suatu pasar modal dapat dikatakan sudah efisien dalam bentuk lemah.

Alternatif lain untuk menguji efisiensi pasar bentuk lemah adalah dengan pengujian runtun (run test). Suatu runtun adalah urutan tanda yang sama dari perubahanperubahan nilai. Misalnya perubahan-perubahan harga sekuritas yang meningkat diberi tanda positis $(+)$, perubahan harga yang menurun diberi tanda negatif (), dan harga sekuritas yang tidak berubah diberi tanda nol (0). Jika perubahan harga sekuritas berkorelasi secara positif dari waktu ke waktu (yang berarti perubahan tanda akan sama dari waktu ke waktu), maka diharapkan akan terjadi sedikit perubahan tanda atau akan terjadi runtun yang sedikit. Jika perubahan harga sekuritas berkorelasi secara negatif dari waktu ke waktu, akan banyak terjadi perubahan tanda negatif atau akan banyak terjadi runtun. Pengujian runtun dapat dilakukan dengan menguji runtun perubahan harga saham ataupun perubahan laba akuntansi.

Adanya indikasi hubungan yang positif antara return hari ini dengan return masa lalu dapat dilihat dari hasil uji korelasi dan run test, meskipun secara rata-rata hubungan tersebut masih bersifat sangat 
lemah. Kadang ditemukan juga adanya korelasi yang bersifat negatif antara return sekarang dengan return yang lalu. Pada pasar yang tidak efisien bentuk lemah, pergerakan return dari waktu ke waktu dapat menunjukkan pola tertentu. Pola yang terjadi dapat berbentuk linier atau cyclical. Misalnya hasil penelitian French(1980) dalam Tandelilin(2001:124) yang menunjukkan bahwa return sekuritas mempunyai pola siklikal dengan return terendah pada hari senin. Jika pola seperti ini, investor dapat menggunakannya sebagai strategi untuk mendapatkan keuntungan lebih tinggi.

\section{Konsep Return}

Return merupakan hasil yang diperoleh dari suatu investasi. Menurut Jogiyanto(2003:109), return saham dibedakan menjadi dua yaitu return realisasi dan return ekspektasi. Return realisasi merupakan return yang sudah terjadi yang dihitung berdasarkan data historis. Return realisasi ini penting dalam mengukur kinerja perusahaan dan sebagai dasar penentuan return dan risiko di masa datang. Return ekspektasi merupakan return yang diharapkan di masa mendatang dan masih bersifat tidak pasti. Investor dihadapkan pada ketidakpastian antara return yang akan diperoleh dengan risiko yang akan dihadapi dalam melakukan investasi. Semakin besar return yang diharapkan akan diperoleh dari investasi, semakin besar pula risikonya, sehingga dikatakan bahwa return ekspektasi memiliki hubungan positif dengan risiko. Risiko yang lebih tinggi biasanya dikorelasikan dengan peluang untuk mendapatkan return yang lebih tinggi pula (high risk high return, low risk low return). Tetapi return yang tinggi tidak selalu hatus disertai dengan investasi yang berisiko. Hal ini bisa saja terjadi pada pasar yang tidak rasional.

Return yang diterima oleh investor di pasar modal dibedakan menjadi dua jenis yaitu current income (pendapatan lancar) dan capital gain/capital loss. Current income adalah keuntungan yang didapat melalui pembayaran yang bersifat periodik seperti dividen. Keuntungan ini biasanya diterima dalam bentuk kas atau setara kas sehingga dapat diuangkan dengan cepat. Misalnya dividen saham yaitu dibayarkan dalam bentuk saham yang bisa dikonversi menjadi uang kas dengan cara menjual saham yang diterimanya, sedangkan capital gain (loss) merupakan selisih laba (rugi) yang dialami oleh pemegang saham karena harga saham sekarang relatif lebih tinggi (rendah) dibandingkan harga sebelumnya. Jika harga saham sekarang (Pt) lebih tinggi dari harga saham periode sebelumnya (Pt-1) maka pemegang saham akan mengalami capital gain. Jika yang terjadi sebaliknya maka pemegang saham akan mengalami capital loss.

Dalam penelitian ini return saham yang digunakan adalah capital gain (loss). Capital gain (loss) merupakan selisih laba (rugi) yang dialami oleh pemegang saham karena harga saham 
sekarang relatif lebih tinggi (rendah) dibandingkan harga saham sebelumnya (Jogiyanto, 2003:109)

\section{Pola Return Sekuritas}

Sejumlah penelitian telah menunjukkan adanya suatu pola dalam return sekuritas. Pola tersebut menunjukkan adanya tingkat return yang lebih tinggi atau lebih rendah pada saat tertentu baik dalam periode harian maupun bulanan. Berikut ini akan diuraikan mengenai pola return sekuritas.

1) Pola harian

Salah satu pola return secara intensif diteliti adalah adanya perbedaan return untuk hari-hari tertentu dalam seminggu. Gibbons dan Hess(1981) dalam Tandelilin(2001:116), menemukan adanya return yang negatif pada hari perdagangan senin yaitu sebesar 33,5 persen. Gibbons dan Hess juga membagi periode tersebut menjadi dua sub periode yaitu $1962 \mathrm{~s} / \mathrm{d} 1970$ dan $1970 \mathrm{~s} / \mathrm{d}$ 1978, dan hasil yang didapat juga sama yaitu terjadi return yang negatif pada hari perdagangan senin. Gibbons dan Hess juga menemukan bahwa return yang positif terjadi pada hari perdagangan rabu dan jumat.

Harris(1968)

dalam

Tandelilin(2001:117), melakukan penelitian mengenai pola return dalam satu hari (intraday pattern) dan hari bursa dalam seminggu (day of the week pattern) dengan menggunakan data 14 bulan dari bulan desember 1981 sampai dengan januari 1983. Harris(1968) menemukan juga bahwa pada hari senin terdapat return yang negatif tetapi pada empat hari lainnya return-nya positif. Return yang negatif di hari senin tidak terjadi sepanjang hari tetapi setengahnya terjadi pada saat penutupan pasar di hari jumat dan pembukaan pasar di hari senin. Setelah pembukaan pasar di hari senin, return di hari senin akan sama dengan hari-hari lainnya. Harris juga menemukan bahwa setiap hari terjadi kenaikan harga pada 30 menit terakhir perdagangan. Hasil penemuan tersebut menyarankan investor untuk menjual saham di hari jumat dan melakukan pembelian sesudah 45 menit pertama perdagangan di hari senin. Perlu diperhatikan bahwa penelitian ini hanya mengamati data dalam waktu yang singkat dan pasar mungkin sudah menyesuaikan pola tersebut, sehingga strategi dengan tersebut tidak akan berhasil mendapatkan abnormal return yang diharapkan.

2) Pola bulanan

Banyak penelitian menemukan bahwa pada bulan januari terdapat return yang lebih tinggi dibandingkan dengan bulan-bulan lainnya dan biasanya terjadi pada saham yang nilainya kecil (small stock). Fama(1991) dalam Tandelilin(2001:117), menemukan bahwa pada periode 1941 sampai dengan 1981, return di bulan januari lebih tinggi dibandingkan bulan-bulan lainnya. Dan perbedaan yang lebih terjadi pada saham yang nilai kapitalisasi pasarnya kecil. Selama periode 1982 sampai dengan january 1991. 
Fama juga menemukan hal yang sama, tetapi perbedaan return di bulan januari untuk small stock dan larger stock tidak terlalu besar. Abnormal return di bulan Januari untuk small stock umumnya relatif tinggi pada hari-hari awal bulan.

\section{Teknik Analisis Data}

Teknik analisis data yang digunakan untuk memecahkan permasalahan dalam penelitian ini meliputi :

1) Menghitung return aktual 42 saham yang masuk dalam LQ45 selama Februari 2017 sampai dengan Januari 2018.

2) Mengelompokkan return tersebut berdasarkan kelompok hari perdagangan saham yaitu return senin, return selasa, return rabu, return kamis, dan return jumat dan mengelompokkannya berdasarkan kelompok bulan perdagangan saham yaitu return harian bulan januari, return harian bulan februari, return harian bulan maret, return harian bulan april, return harian bulan mei, return harian bulan juni, return harian bulan juli, return harian bulan agustus, return harian bulan september, return harian bulan oktober, return harian bulan november dan return harian bulan desember

3) Menghitung rata-rata return masing masing kelompok hari dan bulan perdagangan saham

4) Menguji hipotesis

\section{PEMBAHASAN}

\section{Hasil Penelitian}

Untuk memperjelas dan mempermudah pemahaman atas hasil penelitian ini, terlebih dahulu akan dideskripsikan masing-masing faktor yang menjadi variabel dalam penelitian ini. Dari data harga saham penutupan selama satu tahun yaitu Februari 2017 sampai dengan Januari 2018, diperoleh sebanyak 9996 nilai return aktual (Lampiran 1). Return aktual tersebut selanjutnya akan dikelompokkan berdasarkan hari perdagangan dan bulan perdagangan.

Variabel dalam pengujian the day of the week effect meliputi rata-rata return aktual masing-masing kelompok hari senin sampai jumat. Berdasarkan hasil pengolahan SPSS dapat diperoleh hasil sebagai berikut : 
Tabel 4.2

Deskripsi Statistik Hasil Pengujian The Day Of The Week Effect dalam Perolehan Return

\begin{tabular}{|c|c|c|c|c|c|c|}
\hline & $\mathrm{N}$ & Mean & $\begin{array}{c}\text { Std. } \\
\text { Deviation }\end{array}$ & $\begin{array}{l}\text { Std. } \\
\text { Error }\end{array}$ & $\mathrm{m}_{\mathrm{m}}$ Minimu & ${ }_{\mathrm{m}}$ Maximu \\
\hline SENIN & 1974 & .0007 & .02213 & .00050 & -.14 & .25 \\
\hline SELASA & 2058 & -.0002 & .02321 & .00051 & -.23 & .24 \\
\hline RABU & 2058 & .0011 & .02372 & .00052 & -.17 & .26 \\
\hline KAMIS & 1932 & .0007 & .02103 & .00048 & -.13 & .14 \\
\hline JUMAT & 1974 & .0008 & .02078 & .00047 & -.09 & .13 \\
\hline Total & 9996 & .0006 & .02223 & .00022 & -.23 & .26 \\
\hline
\end{tabular}

Dari tabel 4.2 dapat dilihat bahwa terdapat sejumlah 9996 return aktual yang terdiri dari 1974 return aktual Senin dengan rata-rata return 0,0007 dengan minimum data $-0,14$ dan maximum data $0,25,2058$ return aktual Selasa dengan rata-rata return 0,0002 dengan minimum data $-0,23$ dan maximum data $0,24,2058$ return a]ktual Rabu dengan rata-rata return 0,0011 dengan minimum data $-0,17$ dan maximum data 0,26, 1932 return aktual Kamis dengan rata-rata return 0,0007 dengan minimum data $-0,13$ dan maximum data 0,14, 1974 return aktual Jumat dengan rata-rata return 0,0008 dengan minimum data $-0,09$ dan maximum data 0,13 . Adapun ratarata return aktual tertinggi terlihat pada hari Rabu yaitu sebesar 0,011 dan ratarata return aktual terendah pada hari Selasa yaitu sebesar $-0,0002$.

Variabel dalam pengujian the month of the year effect meliputi rata-rata return aktual bulan Januari sampai bulan Desember. Berdasarkan hasil pengolahan dengan menggunakan SPSS diperoleh hasil sebagai berikut : 
Tabel 4.3

Deskripsi Statistik Hasil Pengujian The Month Of The Year Effect dalam Perolehan Return

\begin{tabular}{|c|c|c|c|c|c|c|}
\hline & $\mathrm{N}$ & Mean & $\begin{array}{c}\text { Std. } \\
\text { Deviation }\end{array}$ & $\begin{array}{l}\text { Std. } \\
\text { Error }\end{array}$ & $\begin{array}{l}\text { Minim } \\
\text { um }\end{array}$ & Maximum \\
\hline JANUARI & 42 & .0040 & .00607 & .00094 & .00 & .02 \\
\hline PEBRUARI & 42 & .0004 & .00546 & .00084 & -.02 & .02 \\
\hline MARET & 42 & .0009 & .00300 & .00046 & .00 & .01 \\
\hline APRIL & 42 & .0008 & .00423 & .00065 & .00 & .02 \\
\hline MEI & 42 & .0002 & .00398 & .00061 & .00 & .01 \\
\hline JUNI & 42 & .0000 & .00383 & .00059 & .00 & .01 \\
\hline JULI & 42 & .0004 & .00427 & .00066 & -.01 & .01 \\
\hline AGUSTUS & 42 & -.0003 & .00456 & .00070 & -.02 & .01 \\
\hline SEPTEMBER & 42 & -.0020 & .00410 & .00063 & -.02 & .00 \\
\hline OKTOBER & 42 & .0021 & .00412 & .00064 & .00 & .01 \\
\hline NOVEMBER & 42 & -.0014 & .00400 & .00062 & .00 & .01 \\
\hline DESEMBER & 42 & .0022 & .00421 & .00065 & .00 & .01 \\
\hline Total & 504 & .0006 & .00460 & .00020 & -.02 & .02 \\
\hline
\end{tabular}

Sumber : Lampiran 2 (data diolah) 2018

Dari tabel 4.3 dapat dilihat bahwa terdapat sejumlah 504 return aktual rata-rata bulanan yang terdiri dari rata-rata return Januari 0,0040 dengan minimum data 0,00 dan maximum data 0,02, rata-rata return Pebruari 0,0004 dengan minimum data 0,02 dan maximum data 0,02, rata-rata return Maret 0,0009 dengan minimum data 0,00 dan maximum data 0,01, rata-rata return April 0,0008 dengan minimum data 0,00 dan maximum data 0,02 , rata-rata return Mei 0,0002 dengan minimum data 0,00 dan maximum data 0,01 , rata-rata return Juni 0,0000 dengan minimum data 0,00 dan maximum data 0,01 , rata-rata return Juli 0,0004 dengan minimum data 0,01 dan maximum data 0,01, rata-rata return Agustus -0,0003 dengan minimum data $-0,02$ dan maximum data 0,01 , rata-rata return September $-0,0020$ dengan minimum data $-0,02$ dan maximum data 0,00 , rata-rata return Oktober 0,0021 dengan minimum data 0,00 dan maximum data 0,01 , rata-rata return November 0,0014 dengan minimum data 0,00 dan maximum data 0,01 , rata-rata return Desember 0,0022 dengan minimum data 0,00 dan maximum data 0,02. Adapun rata-rata return aktual tertinggi terlihat pada bulan Januari sebesar 0,040. 
2. Uji Hipotesis

a. Pengujian The Day Of The

Week Effect dalam Perolehan

Return
Berdasarkan hasil pengolahan data dengan menggunakan SPSS diperoleh hasil sebagai berikut :

Tabel 4.4

Hasil Uji One Way ANOVA The Day Of The Week Effect

\begin{tabular}{|l|r|r|r|r|r|}
\hline & \multicolumn{1}{|c|}{$\begin{array}{c}\text { Sum of } \\
\text { Squares }\end{array}$} & Df & $\begin{array}{c}\text { Mean } \\
\text { Square }\end{array}$ & F & Sig. \\
\hline $\begin{array}{l}\text { Between } \\
\text { Groups } \\
\text { Within } \\
\text { Groups } \\
\text { Total }\end{array}$ & .002 & 4 & .001 & 1.11 & .348 \\
\hline
\end{tabular}

Sumber : Lampiran 1 (data diolah), 2018

Dari tabel 4.4 diperoleh hasil Signifikansi sebesar 0,348 lebih besar dari 0,05. Hal ini menunjukkan bahwa $\mathrm{H}_{0}$ diterima atau rata-rata return masingmasing kelompok hari adalah homogen signifikan. Jadi, dapat disimpulkan bahwa tidak terjadi the day of the week effect di Bursa Efek Indonesia.

b. Pengujian The Month Of The Year Effect dalam Perolehan Return

Berdasarkan hasil pengolahan data dengan menggunakan SPSS diperoleh hasil sebagai berikut :

Tabel 4.5

Hasil Uji One Way ANOVA The Month Of The Year Effect

\begin{tabular}{|l|r|r|r|r|r|}
\hline & $\begin{array}{c}\text { Sum of } \\
\text { Squares }\end{array}$ & df & \multicolumn{1}{|c|}{$\begin{array}{c}\text { Mean } \\
\text { Square }\end{array}$} & F & Sig. \\
\hline Between & .001 & 11 & .000 & 5.687 & .000 \\
Groups & .009 & 492 & .000 & & \\
Within Groups & .011 & 503 & & \\
Total & & & \\
\hline
\end{tabular}

Sumber : Lampiran 2 (data diolah), 2018

Dari tabel 4.5 diperoleh hasil Signifikansi sebesar 0,000 lebih kecil dari 0,05 . Hal ini menunjukkan bahwa rata-rata return masing-masing kelompok bulan adalah tidak homogen signifikan. Jadi, dapat disimpulkan bahwa terjadi The Month Of The Year Effect di Bursa Efek Indonesia berupa January Effect. 
Hal ini dibuktikan dengan adanya return yang signifikan positif (lebih tinggi) terjadi pada bulan Januari atau January Effect. Berdasarkan tabel 5.2 dapat dilihat bahwa rata-rata return bulan Januari sebesar 0,040.

\section{Pembahasan}

\section{a. The Day Of The Week Effect Dalam Perolehan Return}

Hasil analisis One Way ANOVA pada level of signifikan $5 \%$, menunjukkan bahwa tidak terjadi the day of the week effect $\mathrm{di}$ Bursa Efek Indonesia. Dilihat dari hasil uji empiris hal ini membuktikan bahwa hari perdagangan tidak berpengaruh secara signifikan terhadap return saham pada Bursa Efek Indonesia. Jadi, hipotesis pertama dalam penelitian ditolak. Hasil empiris tidak mendukung teori anomali pasar efisien atau the day of the week effect yang menyatakan bahwa tidak terdapat pengaruh hari perdagangan dalam seminggu terhadap return saham.

b. The Month Of The Year Effect Dalam Perolehan Return

Hasil analisis One Way ANOVA pada level of signifikan 5\%, menunjukkan bahwa terjadi the month of the year effect $\mathrm{di}$ Bursa Efek Indonesia. The month of the year effect menunjukkan bahwa rata-rata return bulan berbeda dengan rata-rata return bulan lainnya. Dalam periode penelitian ini, didapatkan bahwa telah terjadi January Effect dimana return Januari lebih besar dibandingkan dengan return bulan lainnya. Jadi, hipotesis kedua dalam penelitian ini dapat diterima. Hasil empiris ini mendukung teori anomali pasar efisien atau the month of the year effect yang menyatakan bahwa terdapat pengaruh bulan perdagangan terhadap return saham.

Faktor-faktor yang menyebabkan January Effect Pertama, fenomena investor individu yang cenderung melepas saham untuk menghindari pajak di akhir tahun (Tax Loss Selling). Kedua, sejumlah fund manager juga biasa menjual sahamsahamnya yang merugi di penghujung tahun untuk mempercantik kinerja dan makin dipercaya klien atau investor. Setelah akhir tahun berlalu, mereka kembali membelinya di awal tahun. Tak terhindarkan lagi, harga saham di Januari naik. Ketiga, sejumlah orang mendapatkan bonus akhir tahun sehingga baru memilih berinvestasi di pasar modal setelah liburan akhir tahun. (kumparan, 2018).

Adanya peningkatan aktivitas selling yang dimana merupakan salah satu indikasi awal terjadi aksi profit taking yang menyebabkan aktivitas penjualan atas saham suatu emiten tersebut akan banyak dijual di pasar bursa sehingga menyebabkan potensi munculnya sentimen negatif dan berpotensi terjadi koreksi negatif terhadap harga saham tersebut. Sehingga dapat diketahui bahwa secara kondisi ekonomi makro Indonesia sangat mendukung iklim investasi di Indonesia namun perilaku investor asing dalam melakukan aksi ambil untung (profit taking) akan berpotensi menimbulkan risiko bagi pasar modal di Indonesia. Aksi ambil untung (profit taking) merupakan 
anomali pasar efesien yang didasarkan pada perolehan abnormal return berdasarkan harga saham periode sebelumnya.

Dilihat dari adanya anomali the month of the year effect berupa January effect di Bursa Efek Indonesia, maka perubahan harga saham di bursa efek indonesia mengikuti pola return sekuritas bulanan. Akibatnya, para pelaku pasar modal baik investor retail maupun manajer investasi akan memperoleh return yang lebih tinggi dengan memanfaatkan pola return sekuritas bulanan. Jadi, dalam penelitian ini the month of the year effect dapat dibuktikan dengan adanya January Effect. Penelitian ini mendukung penelitian yang dilakukan oleh Indah Fitriyani dan Maria M. Ratna Sari (2011) yang menyatakan “ Terdapat perbedaan signifikan antara return saham bulan Januari dengan bulan selain Januari yang berarti January effect terjadi di Bursa Efek Indonesia”.

$$
\text { Hal ini memberikan }
$$
implikasi bagi investor agar melakukan pembelian saham pada bulan selain bulan Januari dan menjualnya pada bulan Januari. Hasil Multiple Comparations menunjukan bahwa terjadi perbedaan signifikan antara ratarata return bulan Januari dengan bulan lainnya. Return paling rendah terjadi pada bulan September dan return tertinggi terjadi pada bulan Januari. Hal tersebut sesuai konsep berinvestasi dimana investor sebaiknya melakukan pembelian pada saat harga mengalami penurunan, kemudian melakukan penjualan pada saat harga sedang mengalami peningkatan.

\section{SIMPULAN DAN SARAN}

\section{A. Kesimpulan}

Berdasarkan hasil penelitian dan pembahasan, dapat disimpukan sebagai berikut:

1) Penelitian ini tidak membuktikan adanya The day of the week effect di Bursa Efek Indonesia periode Februari 2017 - Januari 2018. Hal ini berarti bahwa tidak terdapat perbedaan return masing-masing hari. Hasil empiris ini juga memberikan bukti bahwa tidak terjadi Monday effect di Bursa Efek Indonesia periode Februari 2017 - Januari 2018.

2) Penelitian ini membuktikan adanya The month of the year effect di Bursa Efek Indonesia periode Februari 2017 Januari 2018. Hal ini berarti terdapat perbedaan return masing-masing bulan secara signifikan. Hasil empiris ini juga memberikan bukti bahwa terjadi January Effect di Bursa Efek Indonesia periode Februari 2017 - Januari 2018 dimana rata-rata return tertinggi terjadi pada bulan Januari.

\section{B. Saran}

Berdasarkan hasil penelitian, dapat disampaikan beberapa saran untuk kepentingan pelaku pasar modal maupun peneliti-peneliti selanjutnya sebagai berikut :

1) Tidak adanya fenomena the day of the week effect memberikan implikasi bagi investor bahwa jika melakukan pembelian saham tidak harus menggunakan waktu tertentu 
karena dalam penelitian ini tidak ditemukannya fenomena the day of the week effect .

2) Adanya fenomena the month of the year effect berupa january effect memberikan implikasi bagi investor agar melakukan pembelian saham pada bulan selain bulan Januari dan menjualnya pada bulan Januari. Sesuai dengan konsep investasi dimana investor sebaiknya melakukan pembelian pada saat harga mengalami penurunan, kemudian melakukan penjualan pada saat harga sedang mengalami peningkatan.

3) Penggunaan variabel peneitian dan periode pengamatan yang masih terbatas dalam penelitian ini. Penelitian selanjutnya mengenai The Day of The Week Effect dan The Month Of The Year Effect dalam perolehan return saham di Bursa Efek Indonesia sebagai bentuk anomali pasar, dapat dimodifikasi.

\section{DAFTAR PUSTAKA}

Basher, Syed A. and Sadorsky, Perry. 2006. Day of The Week Effects inEmerging Stock Markets. Journal Applied Economics Letters, 13, 621-628 York University, 4700 Keele Street, Toronto, Ontario M3J 1P3, Canada

Cahyaningdyah, Dwi. 2005. Analisis Pengaruh Hari Perdagangan Terhadap Return Saham: Pengujian Week Four Effect Dan Rogalski Effect Di Bursa Efek Jakarta. Jurnal Ekonomi dan Bisnis Indonesia.vol 20, no.2:175-186
Cochran, Steven J. 2004. Seasonality and Regime Switching in Equity Markets: Evidence from the U.S. and U.K. Managerial Finance. Patrington: 2004. Vol. 30, Edisi 12; pg. 55

Cochran, Steven J. dan Iqbal Mansur. 2004. Nonparametric Investigation of Seasonality in U.S. Stock Market Cycle Durations. Managerial Finance. Patrington: 2004. Vol. 30, Edisi 11; p

Elango, Rengasamy and Nabila Al Macki.2008. Monday Effect and Stock Return Seasonality:

Further Empirical Evidence. The Business Review, Cambridge. Hollywood: Summer 2008. Vol. 10, Edisi 2; pg. 282, 7 pgs

Gumanti, Tatang Ary dan Elok, Sri Utami. 2002. Bentuk Pasar Efisien Dan Pengujiannya. Jurnal Akuntansi \& Keuangan Vol. 4, No. 1, Mei 2002: 54-68

Gumanti, Tatang Ary dan Ma'ruf Farid. 2004. Efek Akhir Pekan Terhadap Return Saham (Studi Kasus Perusahaan LQ45). Jurnal Usahawan No. 11 tahun XXXIII November 2004

Hartono, Jogiyanto. 2005. Pasar Efisien Secara Keputusan. Jakarta: Gramedia Pustaka Utama.

www.yahoo.com

www.idx.co.id 